\title{
Expressed sequence tags in venomous tissue of Scorpaena plumieri (Scorpaeniformes: Scorpaenidae)
}

\author{
Fábio L. S. Costa ${ }^{1}$, Maria E. De Lima ${ }^{1}$, Adriano C. Pimenta ${ }^{1}$, Suely G. Figueiredo ${ }^{2}$, \\ Evanguedes Kalapothakis ${ }^{3}$ and Carlos E. Salas ${ }^{4}$
}

Species of the family Scorpaenidae are responsible for accidents and sporadic casualties by the shore they inhabit. The species Scorpaena plumieri from this family populate the Northeastern and Eastern coast of Brazil causing human envenomation characterized by local and systemic symptoms. In experimental animals the venom induces cardiotoxic, hypotensive, and airway respiratory effects. As first step to identify the venom components we isolated gland mRNA to produce a cDNA library from the fish gland. This report describes the partial sequencing of 356 gland transcripts from S. plumieri. BLAST analysis of transcripts showed that $30 \%$ were unknown sequences, $17 \%$ hypothetical proteins, $17 \%$ related to metabolic enzymes, $14 \%$ belonged to signal transducing functions and the remaining groups (7-8\%) composed by gene related with expressing proteins, regulatory proteins and structural proteins. A considerable number of these EST were not found in available databases suggesting the existence of new proteins and/or functions yet to be discovered. By screening the library with antibodies against a lectin fraction from $S$. plumieri venom we identified several clones whose DNA sequence showed similarities with lectins found in fish. In silico analysis of these clones confirm the identity of these molecules in the venom gland of $S$. plumieri.

Espécies da família Scorpaenidae são responsáveis por acidentes e mortes esporádicas ao longo da costa que habitam. A espécie Scorpaena plumieri desta família povoam a costa Leste e Nordeste do Brasil, causando envenenamento humano caracterizado por sintomas locais e sistêmicos. Em modelos experimentais animais a peçonha induz cardiotoxicidade, efeitos hipotensivos e alterações nas vias aéreas respiratórias. Como primeiro passo para identificar os componentes da peçonha foram isolados os mRNA das glândulas do peixe para produzir uma biblioteca de cDNAs. Esse artigo descreve o sequenciamento parcial de 356 transcritos das glândulas de S. plumieri. Análises em bancos de dados (BLAST) dos transcritos demonstraram que $30 \%$ eram sequências desconhecidas, $17 \%$ proteínas hipotéticas, $17 \%$ relacionadas às enzimas do metabolismo, $14 \%$ pertenciam a funções de transdução de sinais e os demais grupos (7-8\%) formados por genes relacionados com a expressão de proteínas, proteínas regulatórias e estruturais. Um número considerável destes EST não foi encontrado em bases de dados disponíveis, sugerindo a existência de novas proteínas e/ou funções ainda a serem descobertas. Ao fazer um barrido da biblioteca com anticorpos produzidos contra uma fração das lectinas do veneno de S. plumieri, identificamos vários clones, cuja sequência de DNA mostram semelhanças com lectinas encontradas em peixes. A análise in silico destes clones confirmam a identidade destas moléculas na glândula de peçonha de S. plumieri.

Key words: cDNAs, EST, Glands, Lectin, Scorpionfish, Toxins.

\section{Introduction}

The animal kingdom contains more than 100,000 species that synthesize venoms used by the host to protect against predators or to subdue a victim before ingestion (Mebs, 2002). Venomous fish synthesize toxins in specialized glands-like compartments containing spines situated on the chest, dorsal, gill or caudal areas and surrounded by a tegumental sheet (Russel, 1965). Scorpionfish encompasses three groups of venomous fish (Pterois, Scorpaena, and Synanceia) with ubiquitous distribution in tropical and temperate seas (Halstead, 1980; Williamson et al., 1996). The venom contains a myriad of molecules acting on various exogenous substrates, i.e., ion channel, chemical receptors or molecular structures in

${ }^{1}$ Departamento de Bioquímica e Imunologia, Instituto de Ciências Biológicas, Universidade Federal de Minas Gerais. Av. Antônio Carlos, 6627, 1270-901 Belo Horizonte, MG, Brazil. cesbufmg@ icb.ufmg.br (CES)

${ }^{2}$ Departamento de Ciências Fisiológicas, Universidade Federal do Espírito Santo, Vitória, ES, Brazil.

${ }^{3}$ Departamento de Biologia Geral, Instituto de Ciências Biológicas, Universidade Federal de Minas Gerais, Belo Horizonte, MG, Brazil.

${ }^{4}$ Departamento de Biología, Universidad de La Serena, La Serena, Chile. 
target organisms. Some small venom components are already known such as acetylcholine, cathecolamines, and histamine, but mostly unknown proteinaceous molecules are also present (Church \& Hodgson, 2002; Figueiredo et al., 2009).

Scorpaena plumieri known in Brazil as aniquim, mamangá, or moréia-atí is abundant along the Brazilian coast (Menezes \& Figueiredo, 1980; Carvalho-Filho, 1999) and is widely found in shallow-water bottom dwellers, bays, along sandy beaches, rocky coastlines or coral reefs. Specimens have a bizarre appearance, habits of concealing themselves in crevices, among debris, under rocks that together with their protective coloration which blends them almost perfectly into their surrounding environment, makes them difficult to see, predisposing to accidents (Russel, 1965; Schaeffer et al., 1971).

This species is held responsible for accidents that cause injuries to humans, especially, fishermen and professional swimmers. Envenomation is mostly non-life-threatening to humans and is characterized by local edema and erythema. Systemic symptoms such as; cardiotoxic and vasorelaxant effects may be severe, resulting in drastic drop of blood pressure (Carrijo et al., 2005; Boletini-Santos et al., 2008; Haddad et al., 2003; Loyo et al., 2008). During envenomation there is an increase of bronchi and epithelial permeability similar to that observed during erythema or hemorrhage, suggesting a change of cell matrix interactions (Theakston \& Kamiguti, 2002).

A cytolytic toxin (Sp-CTx) has been purified from the venom of $S$. plumieri by hydrophobic interaction and anion exchange chromatographies with estimated molecular mass of $150 \mathrm{kDa}$. Further, the protein is dimeric comprising subunits of approximately $75 \mathrm{kDa}$ each, similar to what has been described in other stonefish species (Gomes et al., 2013). Sp-CTx displays potent hemolytic activity on washed rabbit erythrocytes $\left(\mathrm{EC}_{50} 0.46 \mathrm{nM}\right)$; its effect is antagonized by antivenom raised against stonefish venom - Synanceia trachynis (SFAV). Like S. plumieri whole venom $(100 \mu \mathrm{g} / \mathrm{mL})$, Sp-CTx (1-50 nM) causes a biphasic response on phenylephrine pre-contracted rat aortic rings, characterized by an endothelium- and dose-dependent relaxation phase followed by a contractile phase (Andrich et al., 2010).

However, local envenomation effects are also attributed to the presence of the $\beta$-lectin plumieribetin isolated from $S$. plumieri (De Santana Evangelista, 2009). The fully characterized protein $(14.4 \mathrm{kDa})$ acts as $\alpha 1 \beta 1$ integrin inhibitor similar to monocot mannose-binding B-lectins and to pufflectin found in skin and intestine of Japanese pufferfish/Fugu fish (Takifugu rubripes) (Tsutsui et al., 2003).

Due to limited amounts available of these bioactive molecules and because of their instability, venomous fish have remained unexplored (Figueiredo et al., 2009). The lack of studies of the functional venom genes of $S$. plumieri moved us to generate a cDNA library to analyze by EST, the expressed components of the venom gland. Using this approach we expect to find novel genes, transcription profiling and a comparison with homologous genes found in related species.

\section{Material and Methods}

\section{RNA Extraction}

Wild specimens of Scorpaena plumieri were fished off the coast of Espírito Santo, Brazil and kept in captivity prior to gland dissection. The tissue was extracted from the dorsal and caudal venom glands of two male young adult exemplars and kept in liquid $\mathrm{N}_{2}$ during initial grinding with a tissue grinder mill. The RNA was extracted using guanidinium thiocyanate-phenol-chloroform as described earlier (Chomczynski \& Sacchi, 1987). Poly A RNA was obtained by chromatography of total RNA in oligo-(dT) cellulose. cDNA was synthesized starting with $0.5 \mu \mathrm{g}$ of polyA RNA using the ZAP-cDNA synthesis kit (ZAP-cDNA Gigapack III gold cloning kit, GE). After size fractionation on a CL-2B gel filtration column the cDNA was precipitated, resuspended and ligated to the Uni-ZAP XR vector following the supplier protocol.

\section{Library titration}

The number of clones in the primary library was determined using the relation; $\mathrm{pfu} / \mathrm{mL}={ }^{1} \mathrm{pfu} \times 10^{3} \mu \mathrm{L} / \mathrm{mL} \times$ dilution factor. The recombination efficiency was established by scoring white/blue colonies using $E$. coli XL1-blue cells, in the presence of $2.5 \mathrm{mM}$ IPTG and $50 \mathrm{mg} / \mathrm{mL} X$-gal in DMF. The insert size was determined by PCR of colonies, enzyme digestion of recovered plasmid DNA and 1\% agarose gel electrophoresis. The amplified library was stored at $-80^{\circ} \mathrm{C}$ in $7 \%$ DMSO.

\section{DNA sequencing and analysis}

cDNA clones randomly selected from the library were sequenced at the 5 ' end with the automatic sequencer 3.100 Genetic (Applied Biosystems) according to the protocol provided by the supplier BigDye ${ }^{\mathrm{TM}}$ Terminator Ready Reaction Mix (Sanger, 1977). The processed DNA sequences were analyzed using the NCBI databank (http:// www.ncbi.nlm.nih.gov/blast) to search for similarities. Blast scores higher than 80 and E-values $\leq 10^{-10}$ were considered as significant (Thanh et al., 2011). Protein alignments analysis was done using the tools of Expasy, http://www.expasy.ch).

\section{Library screening with gland venom antibodies fraction.}

The antiserum against a lectin fraction was raised in a rabbit according to standard protocols at the animal house at Ezequiel Dias Foundation R \& D Center (Belo Horizonte, Brazil).The library screening procedure adopted was as previously described with modifications (Ausubel, 1995). Briefly, the phagemid library was plated onto culture plates ( $15 \mathrm{~cm} \varnothing$ ) and grown during $3 \mathrm{~h}$ at $37^{\circ} \mathrm{C}$ before laying onto the plate a nitrocellulose membrane previously soaked with 10 $\mathrm{mM}$ IPTG, and the culture further incubated for $3 \mathrm{~h}$ at $37^{\circ} \mathrm{C}$. The nitrocellulose filters were lysed with buffer: (50 mM Tris$\mathrm{HCl} \mathrm{pH} \mathrm{7.5,} 5 \mathrm{mM} \mathrm{MgCl}, 150 \mathrm{mM} \mathrm{NaCl}, 1 \mu \mathrm{g} / \mathrm{mL}$ DNAase, 40 $\mu \mathrm{g} / \mathrm{mL}$ lysozyme and $3 \% \mathrm{BSA})$. Then, the immunoscreening 
buffer (TBS, $5 \% \mathrm{BSA}_{\text {and }} 3 \mathrm{mM} \mathrm{NaN}_{3}(4 \mathrm{x})$ containing antibody was added at a concentration of $10 \mu \mathrm{g} / \mathrm{mL}(1: 1000)$ in PBS-T for $1 \mathrm{~h}$ at $37^{\circ} \mathrm{C}$. After washings with the immunoscreening buffer, the phosphatase secondary antibody was added and incubated $1 \mathrm{~h}$ at $37^{\circ} \mathrm{C}(1: 10000)$ and following several washings, the filter was developed with BCIP-NBT substrate. Brown colonies were isolated at the master plate after alignment to the membrane and their DNA sequenced.

\section{Results}

Total RNA obtained from fish gland exhibited a 280/260 ratio of 1.9. To verify its integrity an aliquot was electrophoresed on agarose-formaldehyde gel. The result in Fig. 1 shows the 28 and $18 \mathrm{~S}$ rRNA bands plus a smear of RNA. Incubation of the RNA sample during $2 \mathrm{~h}$ at $37^{\circ} \mathrm{C}$ showed no changes in RNA distribution, thus confirming the stability of this preparation. cDNA was prepared using the cDNA synthesis kit provided by Agilent Thecnologies, following the supplier instructions (ZAP-cDNA Gigapack III Gold Cloning Kit, La Jolla, USA). Before ligation to bacteriophage arms the cDNA was sized separated on Sepharose CL-2B to select larger cDNA populations. The pooled cDNA was concentrated and ligated overnight with the Uni-ZAP vector and packaged with Gigapack III Gold packaging extract following the manufacturer instructions (Stratagene Products, La Jolla, USA). Colonies containing insert were selected by adding IPTG, X-gal to plates. The primary library totalized $\mathrm{HH} \sim 1.85 \times 10^{5} \mathrm{pfu}$ and the percentage of recombinants amounted to $90 \%$. Following amplification the title increased to $2.5 \times 10^{9} \mathrm{pfu} / \mathrm{mL}$ and the recombinant ratio decreased to $65 \%$. Mass excision of the library to release the phagemid used $1.85 \times 10^{7}$ pfu and a 100-fold excess of helper Ex-assist phage, as suggested by the supplier (ZAP-cDNA Gigapack III Gold Cloning Kit).

\section{EST sequence and analysis}

Four-hundred and seventy white colonies randomly selected were grown in liquid culture medium and the recovered plasmid DNA quantified by agarose electrophoresis and digested with EcoR1 to confirm the presence of insert (Fig. 2). After removal of the vector contamination by lowquality DNA sequences and ribosomal RNA sequences, 356 individual clones were selected and subjected to further analysis. The EST size were $0.2-0.5 \mathrm{~kb}(31.4 \%), 0.5-1.0 \mathrm{~kb}$ (39.4\%) and 1.0-2.0 $\mathrm{kb}(29.2 \%)$. The purified DNA was sequenced using M13 primers and after sequence edition submitted to Blastn for analysis. The ESTs showing relationship with previously identified sequences were classified in categories using the function attributed to the original sequence. If an EST shared homology with more than one category in the data bank, the classification opted for the main putative function.

The EST distribution in Fig. 3 shows a large number of unknown sequences $(n=107,30 \%)$, followed by $(n=61,17 \%)$ hypothetical proteins (as designated in databanks) and similar
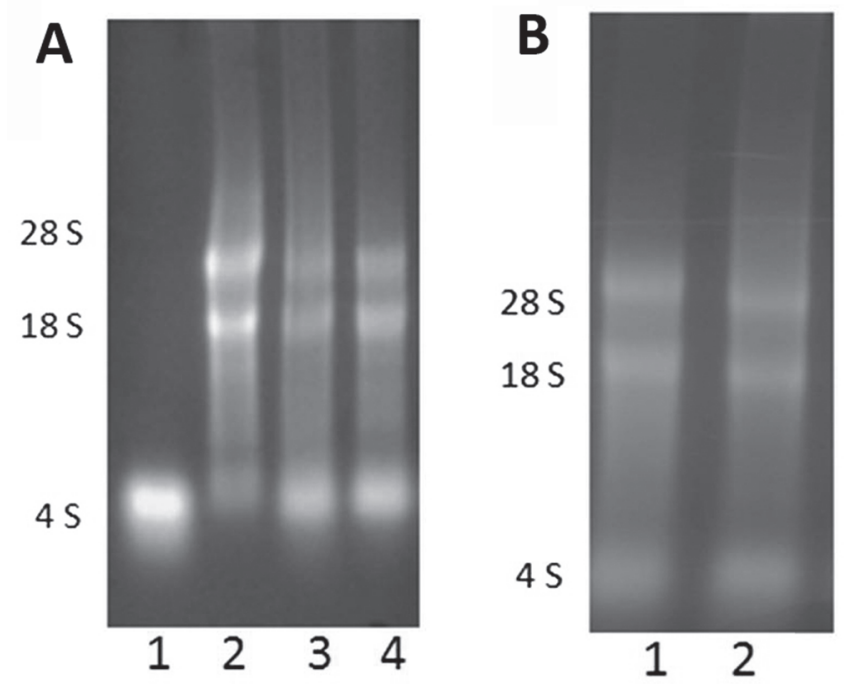

Fig. 1. Agarose- formaldehyde electrophoresis of RNA from Scorpaena plumieri. A) 1) $2 \mu \mathrm{g}$ of E. coli tRNA; 2) $2 \mu \mathrm{g}$ de rRNA de Rattus norvegicus; 3) and 4) $2 \mu$ g total RNA from $S$. plumieri spine gland. B) 1) $2 \mu \mathrm{g}$ de total RNA from S. plumieri; 2) the same sample incubated $2 \mathrm{~h} \mathrm{a} 37^{\circ} \mathrm{C}$ before electrophoresis.

amount of metabolic enzymes $(\mathrm{n}=61,17 \%)$, next, proteins linked to signaling functions ( $\mathrm{n}=49,14 \%)$, and the remaining groups composed by gene expressing proteins, regulatory proteins and structural proteins $(\mathrm{n}=78,7-8 \%)$.

We selected 115 ESTs, whose identities strongly match blastn entries, and scoring $\geq 80$. Table 1 lists the nucleotide putative match and GeneBank accession number for each entry. This list contains, 63 (55\%) single copies and 52 ESTs (46\%) corresponding to two or more copies identified in the library. One-hundred nineteen (33\%) of these ESTs displayed a strong match (score $>401$ ), meanwhile 57 of them $(25 \%)$ had a score between 80 - 400, and the 92 remaining EST (31\%) had a score below 80 .

We next screened the library with antibodies against a venom lectin fraction from S. plumieri and identified several clones sharing homology with lectins from Oplegnathus fasciatus, Dicentrarchus labrax, Maylandia zebra, and Oreochromis niloticus. In this analysis we detected an ORF containing 267 residues sharing three cysteine residues featured by lectins and compatible in size with plumieribetin. The alignment of this lectin-like sequence is shown in Fig. 4. Some invariant amino acid residues (Asp ${ }^{81}$ and $\mathrm{Asn}^{125}$ ) described at the top of the dome-shaped domain structure in all legume lectins sequenced so far $\left(\mathrm{Asp}^{207}\right.$ and $\mathrm{Asn}^{253}$ in this sequence), is responsible for sugar specic recognition (Fig. 4).

\section{Discussion}

Due to the diversity of effects by the venom of Scorpaena plumieri and the lack of information about these venoms, we decided to study the molecular diversity of fish venom. To accomplish this goal, a cDNA library was generated and partial 


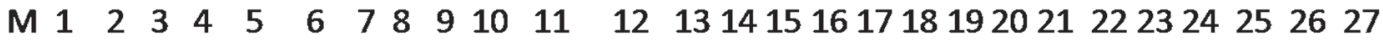

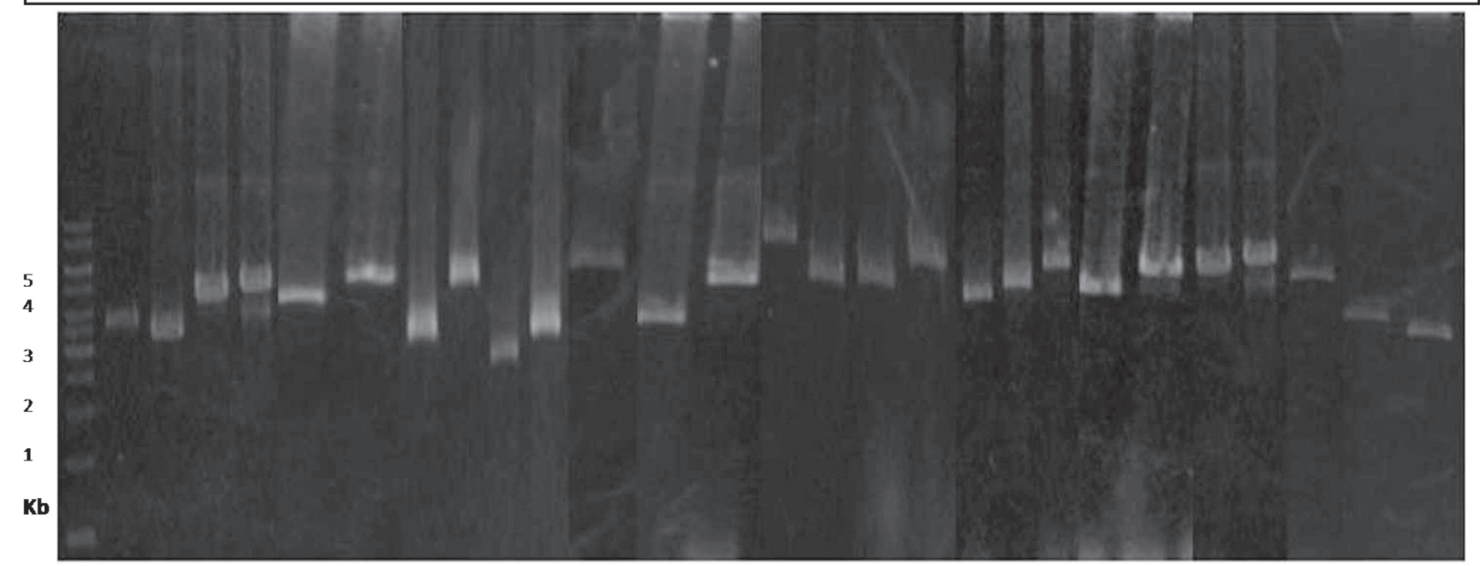

Fig. 2. Agarose gel electrophoresis of DNA isolated from clones. White colonies containing insert were grown and the plasmidial DNA isolated and digested with EcoRI enzyme. An aliquot from each clone (1-27) was electrophoresed on 1\% Agarose gel and stained with ethidium bromide.

sequencing of the cDNAs performed. The expressed sequence tag (EST) approach provides a rapid and reliable method for gene discovery as well as a source of new annotations for analysis of known and unknown expressed transcripts.

As first step to characterize the library, we randomly sequenced 470 colonies containing inserts. After removal of ribosomal RNA sequences and low quality sequences, we generated three-hundred fifty-six ESTs, some of them sharing similarity with previously described sequences found in fish and others species. The majority of inserts had size range between $0.5-1 \mathrm{~Kb}(39 \%)$ and similar amounts (31\%) of smaller size inserts $(0.2-0.5 \mathrm{~Kb})$ and larger inserts $(1-2 \mathrm{~Kb}) 29 \%$. The edited sequences were submitted to Blastn and the resulting matches were classified in categories according to the function originally assigned in the databank. The distribution pie in Fig. 3 shows that $30 \%$ of EST corresponded to unknown sequences, followed by similar amounts (17\%) of hypothetical proteins, metabolic related proteins, and signaling proteins. The large proportion of unknown functions argues for the presence of new non-catalogued proteins and or peptides whose role has not been yet defined. Interestingly, in a similar EST study of fish venom gland from Thalassophryne nattereri it was also described an expressive amount of unknown sequences $(39 \%)$ suggesting the existence of yet unidentified proteins in both marine species (Magalhães et al., 2006). The presence of additional toxic sequences cannot be ruled out at this point since the EST sequencing project is under way.

Among matching sequences we identified a clone whose partial sequence aligned with patoxin- $\beta$ subunit mRNA from Pterois antennata (score 1642) (Table 1). The isolate will be further investigated to establish if corresponds to the complete structure of this toxin, in which case it will be expressed in $E$. coli to study the gene product.

We also found a sequence matching a protein involved in cholesterol transport as; apolipoprotein E precursor and genes related to cell signaling as integrins. $\mathrm{Ca}^{2+}$ binding proteins including a sequence related to $\mathrm{S}-100$ and another to annexin $1 A$, were detected. S-100 protein has been identified in exocrine glands and thought to play a role in secretion (Case et al., 1988). Together with annexin 1A it can form heterocomplexes due to increase in intracellular $\mathrm{Ca}^{2+}$, which stimulates venom secretion. Therefore, the presence of these transcripts in S. plumieri library suggests that these genes might be involved in toxin secretion within the venomous apparatus.

The sequencing of EST showed transcripts that matched fish DNA sequences responsible for protecting proteins from

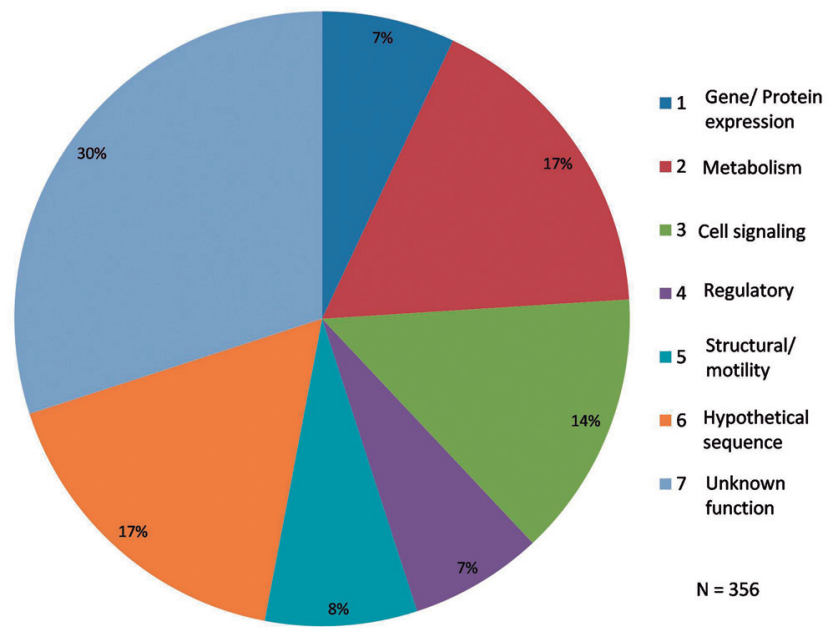

Fig. 3. The classification of EST from Scorpaena plumieri based on their putative fractions. Three-hundred fifty-six EST edited sequences were initially analyzed with Blast and Swiss protein databanks. The consensus sequence was attributed a function based on the strongest match. 
Table 1. Representative list of EST matches with blastn from randomly sequenced clones from Scorpaena plumieri. $\left(\leq 10^{-10}\right.$, score $\geq 80$ ).

\begin{tabular}{|c|c|c|c|}
\hline Group / HIT ID & E-Value (score) & Entry identity & № of ESTs \\
\hline \multicolumn{4}{|l|}{ Metabolism } \\
\hline FJ629181.1 & $0.0(1282)$ & Kinase I & 1 \\
\hline BT083258.1 & 0.0 (1097) & p-21-activated protein kinase & 1 \\
\hline XM_003446848.1 & $0.0(905)$ & $\mathrm{ADP} / \mathrm{ATP}$ translocase 2-like & 2 \\
\hline EU036495.1 & $1 \mathrm{e}-179(640)$ & Cytochrome b & 7 \\
\hline FJ426129.1 & $2 \mathrm{e}-177(632)$ & Chaperonin subunit 7 & 1 \\
\hline DQ900715.1 & $7 e-149(536)$ & Cytochrome $\mathrm{c}$ oxidase subunit II & 3 \\
\hline XM_003459458.1 & $6 e-119(437)$ & $\mathrm{N}$-acetylgalactosaminyltransferase-like & 2 \\
\hline FJ820528.1 & $5 e-70(275)$ & Malate dehydrogenase & 1 \\
\hline XM 003454129.1 & $2 \mathrm{e}-13(86)$ & Protein tyrosine phosphatase type IVA & 1 \\
\hline \multicolumn{4}{|l|}{ Structure/Motility } \\
\hline JF317678.1 & $0.0(1387)$ & $\beta$-actin & 4 \\
\hline JN112540.1 & $0.0(1225)$ & Keratin 8 & 1 \\
\hline AB196514.1 & $0.0(1151)$ & Collagen, type 1, alpha 2 & 5 \\
\hline AF263276.1 & $0.0(959)$ & Alpha tubulin & 1 \\
\hline XM_003449910.1 & $0.0(937)$ & T-complex protein 1 subunit alpha & 1 \\
\hline $\mathrm{AB} \overline{603658.1}$ & $0.0(926)$ & Collagen, type 1 , alpha 3 & 1 \\
\hline AB196514.1 & $0.0(911)$ & Collagen, type 1 , alpha 1 & 3 \\
\hline AB490880.1 & $0.0(699)$ & Ferritin heavy chain & 1 \\
\hline BT082330.1 & $7 e-136(494)$ & Peripheral myelin & 1 \\
\hline DQ364242.1 & $3 e-125(459)$ & Keratin 1 & 2 \\
\hline XM 004070275.1 & $9 \mathrm{e}-100(374)$ & Intermediate filament protein $\mathrm{ON} 3$ & 1 \\
\hline ВТ0ㅛ3320.1 & $3 e-83(318)$ & MANBAL & 1 \\
\hline XM_003452967.1 & $8 \mathrm{e}-43(185)$ & Ubiquitin-conjugating enzyme E2 & 1 \\
\hline XM_002665878.3 & $3 e-23(120)$ & Procollagen, type V, alpha 1 & 1 \\
\hline AY $\overline{7} 87209.2$ & $8 \mathrm{e}-20(107)$ & Cartilage-specific S100-like protein & 1 \\
\hline \multicolumn{4}{|c|}{ Cell signaling/Cell communication } \\
\hline BT028386 & $0.0(1325)$ & Guanine nucleotide binding protein & 3 \\
\hline AB326303.1 & $0.0(1129)$ & Elongation factor 1-alpha & 5 \\
\hline XM_003442398.1 & $0.0(996)$ & Coronin-1A-like & 1 \\
\hline XM_003449701.1 & $0.0(990)$ & Arfaptin-1-like & 1 \\
\hline XM_003449090.1 & $0.0(900)$ & Angiopoietin & 1 \\
\hline FJ45̄5761.1 & $0.0(776)$ & QM-like protein & 1 \\
\hline GU988616.1 & $7 e-161(577)$ & Annexin A11 & 1 \\
\hline XM 003451608.1 & $7 e-161(577)$ & MYC binding protein 2 & 1 \\
\hline ABर̄18145.1 & $1 \mathrm{e}-96(449)$ & Fish-egg lectin & 24 \\
\hline FJ800037.1 & $9 \mathrm{e}-109(403)$ & Apolipoprotein E & 1 \\
\hline AB201746.1 & $3 e-106(394)$ & Lily-type lectin & 1 \\
\hline XM_003441063.1 & $4 \mathrm{e}-100(374)$ & PDZ and LIM domain protein 1-like & 1 \\
\hline GU0̄60308.1 & $1 \mathrm{e}-74(289)$ & S100-like calcium binding protein & 1 \\
\hline HQ441029.1 & $2 e-64(255)$ & Poly A binding protein, citoplasmatic $1 \mathrm{~b}$ & 1 \\
\hline XM_003445768.1 & $6 e-62(248)$ & C3a anaphylatoxin chemotactic receptor & 1 \\
\hline XR_134816.1 & $4 e-52(215)$ & Fibronectin-like & 1 \\
\hline XM_003449138.1 & $1 \mathrm{e}-27(200)$ & von Willebrand factor A domain & 4 \\
\hline X81969.1 & $8 \mathrm{e}-45(190)$ & D1c dopamine receptor & 1 \\
\hline XM_003449453.1 & 1e-41 (179) & SUN domain protein & 1 \\
\hline ВТ0̄44760.1 & $6 e-27(131)$ & Ras-related protein Rab-10 & 1 \\
\hline FJ826549.1 & $5 e-26(129)$ & C-type lectin 7 & 2 \\
\hline FJ826556.1 & $4 \mathrm{e}-21(111)$ & C-type lectin 14 & 1 \\
\hline AB084425.1 & e-20 (109) & Solute carrier family 26 & 1 \\
\hline XM_003438149.1 & 2e-18 (104) & Calcyclin-binding protein & 1 \\
\hline HQ $\overline{44} 1075.1$ & $2 \mathrm{e}-11(80.6)$ & Cofilin-2 & 1 \\
\hline \multicolumn{4}{|l|}{ Regulatory } \\
\hline HQ646108.1 & $0.0(1308)$ & Heat shock cognate 70 & 2 \\
\hline XM_003451520.1 & $0.0(1201)$ & Thrombospondin-4-B-like & 1 \\
\hline FJ644278.1 & $0.0(1090)$ & Heat shock protein 90 & 2 \\
\hline AY647431.1 & $1 \mathrm{e}-142(516)$ & IRF-1 & 1 \\
\hline ВT046051.1 & $3 e-31(145)$ & Profilin-2 & 1 \\
\hline XM_003455475.1 & $4 e-30(141)$ & Thymosin beta-12-like & 2 \\
\hline XM 003437992.1 & $2 \mathrm{e}-26(129)$ & Integrin alpha-6-like & 1 \\
\hline AJ5556548.1 & $2 \mathrm{e}-16(96.9)$ & TRAF4 protein & 1 \\
\hline HQ447060.1 & $2 \mathrm{e}-12(84.2)$ & Haplotype 2 AFGP/TLP & 1 \\
\hline \multicolumn{4}{|l|}{ Others } \\
\hline AB623221.1 & $0.0(1642)$ & Patoxin subunit $b$ & 1 \\
\hline
\end{tabular}




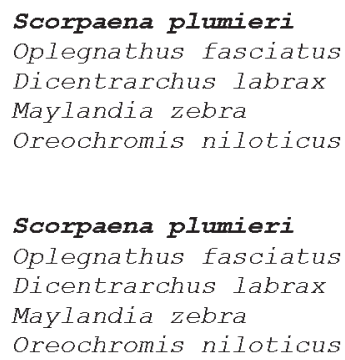

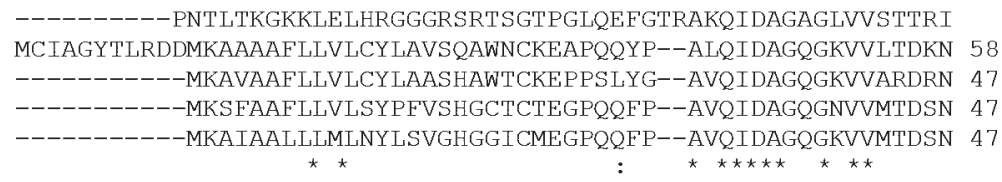

HFAYMLVNGFWIRLSTI-RVRHVTVGKAGIWAAGKFNKVYRYLCGRFRHAKGKSMKQVDA HNAYFLSGSTWYRLGSY-SLKHVSVGPAGIWGVDTSNKVYKYVAGNFLLSNGPSMLQVDA 117 YYAYFLSGTTWQRLGSYRALKHVSVGPAGIWAVDTSNRVHKYVAGNFKLSSGGYMQQVDA 107 NYAYFLLGSQWYKMGSL-TLKHVSVGPAGIWGVDLDDRVYKYVAGSFVFANGESLQQVDA 106 NYAYFLIGSQWYKMGLL-TLKHVSVGPAGIWGVDLNNRVYEYVAGSFVFANGESLRQVDA 106

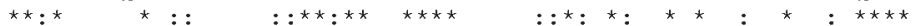

GGHCNIVGVTPTNQANELRKQHAMAFNGNGALFWKVIRNRFRTMKYISTTFNGRSPSWGV GGNGQVVGVSNSYTNYGLRSTFASAYRKVGSLTWNSLS---RVVKYYSCGP--LYGCWGV 172 GGDGQVVGVNNNYYAYGLRSTYASVYRGSGSLRWSSLG---RIMRYYSCSP--LNGCWGV 162 GGDGQVVGVTDTSTIHELKSTIASAYREQSTLSWTTLP---GLLMYVSCSS--KYGCWGV 161 GGDGQVVGVTDTSTIHELQSTIASVYREQSTLSWITLP---GLLMYVSCST--KYGCWGV 161

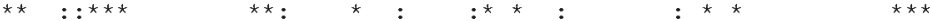

LSNHKVVCSQVSNSKTEIFSRWKIVKGLLTMVEVGNDGTVVGVTKIGKVVQRLGISKRFP DASDRIYF"TQRI IPTTEGTSGWTQISGSAKMVEVGTDGTVFTVNRQGLVFQRTGIYNGRP 232 DTSNRIYFTQRITPTTESISGWVRVSGSAKMVEVGTDGNVFMLGVDGRVYQRAGISSSRP 222 NSVQNIYFTR-VTPSTCGISGWIQVDGLAVMVEIGTDGSVFVVNRGGEVFQRQGIDSSTP 220 NSAENIYFTK-VTPSTEGISDWIHVDGLAVKVETGTDGSVFVVNRVGEVYQRQGIDSRTP 220

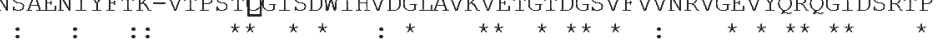

HGTSWKYVPMCMAIRHVTYDVGNLWAVSRTGFIFK RRI QGSGWTQVSMCMKINHVSYDLGNLLWAVTTSGLLFOFTH 270 YGTSWTRINLCLPI LHVSYDLGNL----------- -- 246 QGTSWTKIPMPSRINHVSYDRGNLWVVTDYGTILK FFC 258 QGTSWTQIPMPSRISHVSYDRGNLWVVTDNGTILKELY 258

Fig. 4. Sequence alignment of putative lectin from Scorpaena plumieri. Alignment of a lectin-like EST in silico translated sequence from S. plumieri (ClustalW2 EBI) with fish-egg lectin from Oplegnathus fasciatus (BAL618145), Dicentrarchus labrax (CBK52298), Maylandia zebra (XP_004574029), and Oreochromis niloticus (XP003443389). The recombinant clone was isolated with antibody fraction derived from $S$. plumieri venom. * identifies and identical residue; : identifies a conserved residue. Underlined residues represent invariable sites, underlined IRLS $=\mathrm{N}$-acetylation site.

degradation and necessary during post-translational processing (Hsp70, Hsp90, and one chaperonin subunit). Heat shock proteins and other chaperonins are a subset of ubiquitous proteins that direct the folding and assembly of cellular proteins (Welch, 1991). Recent reports show that Hsps levels increase in fish tissues in response to a variety of environmental and biological stressors (Iwama et al., 1999). Interestingly, we also found genes involved in homeostasis, such as fibronectin-like, angiopoietin, and von Willebrand factor, as well as defense genes involved in the immune response, such as the immunoglobulin heavy chain, thymosin, coronin-1A-like and IRF-1, an a transcription factor that plays a critical role in antiviral defense and immune response (Shi et al., 2010). ESTs showing homology with genes related to innate immunity, such as ferritin, thrombospondin and fish egg lectins were also found in the library.

Fish egg lectins were highly abundant in venom glands of $S$. plumieri and few have been already reported in marine animals, particularly fish. A chemoattractant lectin from the dorsal spines of the redfin velvetfish, Hypodytes rubripinnis (= Paracentropogon rubripinnis) was isolated and reported its chemoattractant activity. This glycoprotein induced agglutination of rabbit erythrocytes and was effectively inhibited by D-mannose (Shinohara et al., 2010).

We next screened the library with antibodies against a venom lectin fraction from $S$. plumieri and identified several clones sharing homology with lectins from Oplegnathus fasciatus, Dicentrarchus labrax, Maylandia zebra, and Oreochromis niloticus (Fig. 4). Lectins are agglutinating proteins that recognize specific glycoproteins and glycoconjugates at the cell surface.

In a recent study a lectin-like molecule called plumieribetin was described in venomous glands of $S$. plumieri that inhibits integrin binding to collagen IV from the basement membrane. The inhibition contributes to the local and systemic effect of envenomation by scorpionfish (De Santana Evangelista, 2009). Plumieribetin is a homotetrameric protein displaying high content of antiparallel B-strands, similar to the mannosebinding monocotiledons-B-lectins. Plumieribetin lacks Nlinked glycoconjugates and common O-glycan motifs found in plant B-lectins, these modifications are necessary for binding of plant lectins to integrins, therefore, it was proposed that plumieribetin binds directly to integrins. The fully characterized protein $(14.4 \mathrm{kDa})$ acts as $\alpha 1 \beta 1$ integrin inhibitor similar to monocot mannose-binding B-lectins and to pufflectin found in skin and intestine of Japanese pufferfish/Fugu fish (Takifugu rubripes) (Tsutsui et al., 2003). 
Analysis of the lectin-like sequence in the library identified an ORF with 267 residues displaying three cysteine residues also featured by lectins and compatible in size with plumieribetin. The alignment of this lectin-like sequence is shown in Fig. 4. Some invariant amino acid residues $\left(\mathrm{Asp}^{81}\right.$ and $A s n^{125}$ ) described at the top of the dome-shaped domain structure in all legume lectins sequenced so far $\left(\mathrm{Asp}^{207}\right.$ and $\mathrm{Asn}^{253}$ in this sequence), are responsible for sugar specic recognition (Fig. 4).

In silico analysis (Expasy, BLAST, UniProt) of the consensus sequence suggests the presence of the $\beta$-propeller structure found also in tachylectin-2, a five-blade propeller domain described in Tachypleus tridentatus crab (Medzhitov \& Janeway, 1997). Inspection of potentially modified sites shows absence of glycosylation sites, one $\mathrm{N}$-acetylation site and six lysine glycation sites. Prediction of secondary structures Expasy, SOPMA) suggests the prevalence of tandem $\beta$-sheets $(41 \%)$, followed by random coil $(39 \%)$ and $\alpha$-helix $(9 \%)$. The presence of tandem $\beta$-sheets has been frequently reported in mannose binding plant lectins (Barre et al., 2001). However, it is possible that fish-toxin lectins may contribute with the local and systemic effects observed on envenomation such as severe pain, swelling and fever (Shinomara et al., 2010). Future experiments must address the expression of this protein to evaluate its biological activity.

\section{Acknowledgments}

The authors wish to acknowledge the financial support from FAPEMIG (Fundação de Amparo à Pesquisa do Estado de Minas Gerais), CNPq, (Conselho Nacional de Desenvolvimento Científico e Tecnológico), INCTTOX (Instituto Nacional de Ciência e Tecnologia em Toxinas and CAPES (Coordenação de Aperfeiçoamento de Pessoal de Nível Superior.

\section{Literature Cited}

Andrich, F., J. B. T. Carnielli, J. S. Cassoli, R. Q. Lautner, R. A. S. Santos, A. M. C. Pimenta, M. E. De Lima \& S. G. Figueiredo. 2010. A potent vasoactive cytolysin isolated from Scorpaena plumieri scorpionfish venom. Toxicon, 56: 487-496.

Ausubel, F. M. 1995. Current Protocols in Molecular Biology. Ausubel, F. M., R. Brent, R. E. Kingston, D. D. Moore, J. G. Seidman, J. A. Smith \& K. Struhl (Eds). John Wiley and Sons Inc. Hoboken, NJ, USA.

Boletini-Santos, D., E. N. Komegae, S. G. Figueiredo, V. Haddad Jr., M. Lopes-Ferreira \& C. Lima. 2008. Systemic response induced by Scorpaena plumieri fish venom initiates acute lung injury in mice. Toxicon, 51: 585-596.

Barre, A., Y. Bourne, E. J. M. Van Damme, W. J. Peumans \& P. Rougé. 2001.Mannose-binding plant lectins: Different structural scaffolds for a common sugar-recognition process. Biochimie, 83: 645-651.

Carrijo, L. C., F. Andrich, M. E. De Lima, M. N. Cordeiro, M. Richardson \& S. G. Figueiredo. 2005. Biological properties of the venom from the scorpionfish (Scorpaena plumieri) and purification of a gelatinolytic protease. Toxicon, 45: 843-850.
Carvalho-Filho, A. 1999. Fishes: Brazilian Coast. Ed. Melro: São Paulo.

Case, R. M., A. Ansah, T. S. Dho, A. Miziniak \& L. Wilson, 1988. Calcium homeostasis in exocrine secretory cells. Pp. 211-219. In: Gerday, C.H., R. Gilles \& L. Bolis (Eds.)., Calcium and calcium binding proteins. Molecular and functional aspects, Springer, Berlin Heidelberg New York.

Chomczynski, P. \& N. Sacchi. 1987. Single-step method of RNA isolation by acid guanidinium thiocyanate-phenol-chloroform extraction. Analytical Biochemistry, 162:156-159.

Church, J. E. \& W. C. Hodgson. 2002. The pharmacological activity of fish venoms. Toxicon, 40: 1083-1093.

De Santana Evangelista, K., F. Andrich, R. F. Figueiredo, S. Niland, M. N. Cordeiro, T. Horlacher, R. Castelli, A. Schmidt-Hederich, P. H. Seeberger, E. F. Sanchez, M. Richardson, S. G. Figueiredo \& J. A. Eble. 2009. Plumieribetin, a fish lectin homologous to mannose-binding B-type lectins, inhibits the collagen-binding alphal beta1 integrin The Journal of Biological Chemistry, 284: 34747-34759.

Figueiredo, S. G., F. Andrich, C. Lima, M. Lopes-Ferreira \& V. Jr. Haddad. 2009. Venomous Fish: A brief overview. Pp. 73-95. In: De Lima, M. E., A. M. C. Pimenta, M. F. Martin-Eauclaire, R. Zingali \& H. Rochat (Eds.). Animal toxins: State of the art. Perspectives on Health and Biotechnology, 1st ed. Federal University of Minas Gerais, Belo Horizonte.

Gomes, H. L., F. Andrich, C. L. Forte-Dias, J. Perales, A. TeixeiraFerreira, D. V. Vassalo, J. S. Cruz \& S. G. Figueiredo. 2013. Molecular and biochemical characterization of a cytolysin from the Scorpaena plumieri (scropionfish) venom: evidence of pore formation on erythrocyte cell membrane, Toxicon 74: 92-100.

Haddad Jr. V., I. A. Martins \& H. M. Makyama. 2003. Injuries caused by scorpion fishes (Scorpaena plumieri Bloch, 1789 and Scorpaena brasiliensis Cuvier, 1829) in the Southwestern Atlantic Ocean (Brazilian coast): epidemiologic, clinic and therapeutic aspects of 23 stings in humans. Toxicon 42: 79-83.

Halstead, B.W. 1980. Dangerous marine animals: that bites, sting, shock, are non-edible. Pp. 108-117. In: Halstead, B. W. (Ed.). Dangerous Marine Animals, $2^{\text {nd }}$ Ed. Cornell Maritime Press: Centreville Maryland.

Iwana, G. K., M. M. Vijayan, R. B. Forsyth \& P. A. Ackerman, 1999. Heat shock proteins and physiological stress in fish. American Zoologist, 39: 901-909.

Loyo, J., L. Lugo, D. Cazorla \& M. E. Acosta. 2008. Scorpionfish (Scorpaena plumieri) envenomation in fishing and touristic community of Paraguaná peninsula, Falcón state, Venezuela: clinical, epidemiological and treatment aspects. Investigación Clínica, 49: 299-307.

Magalhães, G. S., I. L. M. Junqueira-de-Azevedo, M. Lopes-Ferreira, D. M. Lorenzini, P. L. Ho \& A. M. Moura-da-Silva. 2006. Transcriptome analysis of expressed sequence tags from the venom glands of the fish Thalassophryne nattereri. Biochimie, 88: 693-699.

Mebs, D. 2002. Venomous and Poisonous Animals: A handbook for biologists, toxicologists and toxinologists, physicians and pharmacists. Medpharm Scientific Publisher: Germany.

Medzhitov, R. \& C. A. Janeway. 1997. Innate immunity: the virtues of a nonclonal system of recognition. Cell, 91: 295-298.

Menezes, N. A. \& J. L. Figueiredo. 1980. Manual de peixes marinhos do sudeste do Brasil. IV. Teleostei (3). São Paulo, Museu de Zoologia da Universidade de São Paulo, 96 p.

Russel, F. E. 1965. Marine toxins and venomous and poisonous marine animals. Pp. 137-141. In: Russel, F. S. (Ed.). Advances 
in Marine Biology, $2^{\text {nd }}$ ed. Academic Press, London.

Sanger, F., S. Nicklen \& A. R. Coulson. 1977. DNA sequencing with chain-terminating inhibitors. Proceedings of National Academy of Sciences, 74: 5463-5467.

Schaeffer, R. C. Jr., R. W. Carlson \& F. E. Russel, 1971. Some chemical properties of the venom of the scorpionfish Scorpaena guttata. Toxicon, 9: 69-78.

Shi, Y., X. P. Zhu, J. K. Yin, Q. Y. Zhang \& J. F. Gui. 2010. Identification and characterization of interferon regulatory factor-1 from orange-spotted grouper (Epinephelus coioides). Molecular Biology Reports, 37: 1483-1493.

Shinomara, M., K. Nagasaka, H. Nakagawa, K. Edo, H. Sakai, K. Kato, F. Iwaki, K. Ohura \& H. Sakuraba, 2010. A novel chemoattractant lectin, karatoxin, from the dorsal spines of the small scorpionfish Hypodytes rubripinnis. Journal of Pharmacological Sciences, 113: 414-417.

Thanh, T., V. T. Chi, M. P. Abdullah, H. Omar, M. K. H. Noroozi \& S. Napis. 2011. Construction of cDNA library and preliminary analysis of expressed sequence tags from green microalga Ankistrodesmus convolutes Corda Molecular Biology Reports, 38: 177-182.

Theakston, R. D. \& A. S. Kamiguti. 2002. A list of animal toxins and some other natural products with biological activity. Toxicon, 40: 579-651.

Tsutsui, S., M. Okamoto, S. Tassumi, H. Suetake \& Y. Suzuki. 2003. Lectins homologous to those of monocotyledonous plants in the skin mucus and intestine of Pufferfish, Fugu rubripes. The Journal of Biological Chemistry, 278: 20882-20889.

Welch, W. J. 1991.The role of heat-shock proteins as molecular chaperones. Current Opinion in Cell Biology. 3: 1033-1038.

Williamson, J. A., P. J. Fenner \& J. W. Burnett. 1996. Venomous and poisonous marine animals. Pp. 375-386. In: A medical and biological handbook, $1^{\text {st }}$ ed. University of New South Wales Press: Sydney.

Submitted September 5, 2013

Accepted April 11, 2014 by Bernardo Baldisserotto 